\title{
PENGGUNAAN MEDIA KONKRET UNTUK MENINGKATKAN HASIL BELAJAR MATEMATIKA POKOK BAHASAN GARIS BILANGAN PADA PESERTA DIDIK KELAS III MI DATOK SULAIMAN KOTA PALOPO
}

\author{
Sri Sulviani \\ Institut Agama Islam Negeri Palopo \\ Jl. Agatis Balandai, Kota Palopo \\ E-mail: srisulviani@ymail.com
}

\begin{abstract}
This research is a Classroom Action Research (CAR) which is the main problem of the low level of mathematics learning outcomes of class III students of MI Datok Sulaiman Palopo City. The research subjects were MI Datok Sulaiman third grade students in the odd semester of 2018/2019 school year with 28 students. This study was carried out in two cycles with number line material. Data collection techniques used consist of tests, observations, and documentation. Data processing and analysis techniques used are quantitative data analysis and qualitative analysis. The results showed that the learning outcomes with the number line material obtained by the average learning outcomes of students in cycle I was 64.85 including the category of not achieving the KKM score (Minimum Completeness Criteria) with the number of students completing learning were 11 people with a percentage of $39 \%$, and learning outcomes in the second cycle on average obtained 82.89 including very good category with the number of students completing 26 with a percentage of $93 \%$. This research was declared successful with the use of concrete media to improve mathematics learning outcomes.
\end{abstract}

\section{Keywords: Concrete Media, Mathematics Learning Outcomes, Number Lines}

\begin{abstract}
Abstrak: Penelitian ini merupakan Penelitian Tindakan Kelas (PTK) yang masalah utamanya rendahnya hasil belajar matematika peserta didik kelas III MI Datok Sulaiman Kota Palopo. Subjek penelitian adalah peserta didik kelas III MI Datok Sulaiman pada semester ganjil tahun pelajaran 2018/2019 dengan jumlah peserta didik 28 orang. Penelitian ini dilaksanakan dua siklus dengan materi garis bilangan. Teknik pengumpulan data yang digunakan terdiri dari tes, observasi, dan dokumentasi. Teknik pengolahan dan analisis data yang digunakan yaitu analisis data kuantitatif dan analisis kualitatif. Hasil penelitian menunjukkan bahwa hasil belajar dengan materi garis bilangan diperoleh rata-rata hasil belajar peserta didik pada siklus I adalah 64,85 termasuk kategori belum mencapai nilai KKM (Kriteria Ketuntasan Minimal) dengan jumlah peserta didik tuntas belajar adalah 11 orang dengan persentase 39\%, dan hasil belajar pada siklus II rata-rata diperoleh 82,89 termasuk kategori sangat baik dengan jumlah peserta didik tuntas 26 dengan persentase 93\%. Penelitian ini dinyatakan berhasil dengan penggunaan media konkret untuk meningkatkan hasil belajar matematika.
\end{abstract}

\section{Kata Kunci: Media Konkret, Hasil Belajar Matematika, Garis Bilangan}

\section{PENDAHULUAN}

Pembelajaran matematika merupakan pelajaran dasar yang diperlukan untuk meningkatkan atau menguasai pengetahuan dan teknologi. Perkembangan teknologi dan ilmu pengetahuan saat ini turut andil dalam mempersatukan bangsa-bangsa dalam berbagai sektor kehidupan secara menyeluruh (Rustan, 2001). Oleh karena itu, semua orang perlu untuk mengenal, memahami peran, dan manfaat matematika. Peran matematika di 


\section{2 | Sri Sulviani}

dunia telah dijelaskan dalam Q.S Al-Qamar bahwa "Sesungguhnya Kami menciptakan segala sesuatu menurut ukuran". Kementrian Agama Republik Indonesia (2016:530). Segala sesuatu yang ada di muka bumi ini memiliki ukuran, rumus, hitungan, dan lain sebagainya. Mata pelajaran matematika diajarkan mulai dari jenjang Sekolah Dasar (SD) sampai perguruan tinggi (minimal sebagai mata kuliah umum). Karena dalam mata pelajaran matematika, siswa secara bertahap dapat mengembangkan kemampuan berfikir logis, analisis, sistematis, kritis dan kreatif. Beth dan Piaget dalam buku Tombokan Runtukahu (2014:28) mengatakan bahwa "matematika adalah pengetahuan yang berkaitan dengan berbagai struktur abstrak dan hubungan antar-struktur terorganisasi dengan baik".

Dalam mencapai keberhasilan proses pendidikan diperlukan kebijakan-kebijakan yang tertuang dalam peran dan fungsi kurikulum (Rustan, Hanifah, \& Kanro, 2018). Kurikulum Tingkat Satuan Pendidikan (KTSP) matematika Sekolah Dasar, terdapat beberapa materi pelajaran matematika yang harus dipahami oleh peserta didik, salah satunya adalah materi garis bilangan. Untuk materi garis bilangan pada peserta didik kelas III media yang sesuai adalah media benda konkret. Pembelajaran menggunakan media konkret sangat tepat bagi anak usia sekolah dasar karena peserta didik dapat melihat, merasakan dan meraba alat peraga yang digunakan oleh guru.

Berdasarkan hasil observasi yang dilakukan oleh peneliti di sekolah tersebut mengungkapkan bahwa hasil belajar peserta didik masih tergolong rendah. Hal ini disebabkan karena peserta didik tidak dilibatkan langsung sehingga peserta didik kurang antusias dan malas ketika diberi tugas untuk menghitung, ternyata peserta didik belum mampu menghitung dan kebanyakan menghayal karena guru monoton menggunakan metode ceramah. Guru kurang menggunakan media pembelajaran yang dapat memudahkan peserta didik untuk lebih mudah memahami pelajaran. Setiap kali pembelajaran Matematika, peserta didik kebanyakan menghayal karena matematika merupakan pelajaran yang masih abstrak. Akibatnya, peserta didik tidak mampu menghitung dengan baik. Dapat diketahui dari tabel kategori kemampuan awal peserta didik yakni 1 peserta didik yang mendapat nilai kategori baik, 2 peserta didik yang mendapat nilai kategori cukup, 5 peserta didik yang mendapat nilai kategori kurang, dan 20 peserta didik yang mendapat nilai kategori gagal. Oleh karena itu, secara umum hasil belajar peserta didik bisa dikatakan sangat rendah, karena baru 1 peserta didik atau 4\% yang nilainya dapat memenuhi Kriteria Ketuntasan Minimum 
(KKM) yaitu 70. Dengan nilai rata-rata yang diperoleh yaitu 47 atau secara klasikal sebesar 4\%.

Permasalahan ini harus diatasi agar kualitas pembelajaran di sekolah yang dilakukan oleh guru dapat meningkatkan hasil belajar peserta didik. salah satu upaya yang digunakan adalah penggunaan media yang tepat. Salah satu media yang dapat digunakan guru adalah media konkret. Peserta didik diberi kesempatan oleh guru untuk mempelajari dan memahami pembelajaran matematika pada materi garis bilangan dengan bantuan media konkret. Media ini sangat membantu peserta didik yang kesulitan menghitung.

Matematika merupakan ilmu yang mendasari perkembangan teknologi modern. "Perkembangan ilmu pengetahuan dan teknologi mendorong upaya pembaruan pemanfaatan hasil teknologi dalam proses belajar". Azhar Arsyad (2016:2). Menurut Hamalik dalam buku Ahmad Susanto "belajar merupakan suatu proses kegiatan mengalami pembelajaran". Ahmad Susanto (2014:3). Menurut Kamus Besar Bahasa Indonesia belajar berarti berusaha memperoleh kepandaian atau ilmu. (2011:17). Matematika dalam bahasa Latin disebut manthanein atau mathema yang berarti "belajar atau hal yang dipelajari," sedangkan dalam bahasa Belanda, matematika disebut wiskunde atau ilmu pasti. Ahmad Susanto (2014:184). Belajar mengajar merupakan suatu kegiatan yang bernilai edukatif yakni interaksi antara guru dengan peserta didik yang dilakukan untuk mencapai tujuan yang telah ditetapkan sebelum pengajaran berlangsung. Syaiful Bahri Djamarah dan Aswan Zain (2012:1). Selain itu, matematika juga merupakan sarana berpikir dalam mengembangkan ilmu pengetahuan dan teknologi.

Menurut Baharim Shamsudin "garis bilangan merupakan garis lurus untuk meletakkan bilangan yang ditandai dengan sejumlah titik yang berjarak sama panjang. Nurul Masitoch $d k k$ (2009:4). Penempatan bilangan pada garis bilangan diurutkan dari bilangan yang lebih kecil ke bilangan yang lebih besar. Suharyono (2009:56). Bilangan diurutkan dari bilangan negatif terkecil sebelah kiri nol sampai terbesar di sebelah kanan nol. Muatan pembelajaran matematika pokok bahasan garis bilangan antara lain mengurutkan bilangan pada garis bilangan, menentukan letak bilangan dan pola bilangan, melengkapi garis bilangan, penjumlahan dan pengurangan bilangan bulat positif. Menurut Association for Education and Communication Technology (AECT) media merupakan segala bentuk yang digunakan untuk menyampaikan informasi. Asnawir dan Basyiruddin Usman (2012:11). Kata media berasal dari bahasa Latin dan merupakan bentuk jamak dari kata medium yang secara harfiah berarti perantara atau 


\section{4 | Sri Sulviani}

pengantar. Arief S. Sadiman $d k k$ (2012:6). Menurut R. Ibrahim dan Nana Syaodih S dalam buku Rusman "media adalah segala sesuatu yang dapat digunakan untuk menyampaikan materi pembelajaran dalam proses pembelajaran”. Rusman (2016:77). Sedangkan menurut Gagne' dan Briggs dalam buku Azhar Arsyad "media pembelajaran merupakan alat untuk menyampaikan materi pembelajaran”. Azhar Arsyad (2016:4). Dengan demikian, media merupakan wahana penyalur informasi belajar atau penyalur pesan. Syaiful Bahri Djamarah dan Aswan Zain (2012:136). Konkret adalah benda yang dapat dijadikan sebagai media pembelajaran. Menurut Kamus Besar Bahasa Indonesia, konkret adalah nyata; benar-benar ada (berwujud, dapat dilihat, diraba, dan sebagainya). (2011:588). Jadi, media konret yang dimaksud adalah alat peraga yang dapat dilihat, diraba, dan dirasakan oleh peserta didik. Untuk mencapai hasil yang optimal dari proses pembelajaran, maka digunakan media yang bersifat nyata untuk me rangsang pengembangan keterampilan peserta didik. R. Ibrahim dan Syaodih (2010:118-119). Peserta didik belajar melalui benda konkret untuk memahami konsep yang abstrak melalui alat peraga yang dapat menmbantu proses pembelajaran yang efektif. Hasri (2013:12). Hasil riset BAVA (British Audio Visual Aids) memaparkan bahwa hasil pembelajaran yang tidak menggunakan media hanya terserap 13\% sedangkan pembelajaran yang menggunakan media terserap sampai 86\%. Rusman. (2016:123-124). Menurut Ibrahim dan Syaodih media konkret memiliki keuntungan yaitu dapat memberikan kesempatan semaksimal mungkin pada peserta didik untuk mempelajari sesuatu dalam situasi nyata, sedangkan kelemahannya adalah biaya yang diperlukan kadang-kadang tidak sedikit dan biasanya terjadi kerusakan. R. Ibrahim dan Syaodih (2010:119).

Dalam pembelajaran matematika media pembelajaran dimanfaatkan untuk meningkatkan daya serap peserta didik terhadap materi yang diberikan oleh guru. Oleh karena itu, guru sangat berperan penting dalam merancang media pembelajaran yang cocok digunakan pada saat proses pembelajaran. Ali Hamzah dan Muhlisrarini (2014:96-97). Media pembelajaran yang diterapkan dalam proses pembelajaran akan menarik perhatian dan minat belajar peserta didik akan meningkat serta meminimalisir kesulitan peserta didik dalam memahami materi pelajaran. Untuk mencapai tujuan pembelajaran yang ditetapkan, guru dapat menggunakan alat bantu dengan memanfaatkan alat-alat yang telah tersedia ataupun mengembangkan keterampilan yang dimiliki untuk membuat media pembelajaran apabila belum tersedia di sekolah. Menurut Benjamin S. Blo om ada tiga ranah hasil belajar yakni ranah kognitif, afektif, dan psikomotorik. Asep Jihad dan abdul Haris (2013:14). Hasil belajar dapat berupa perubahan PiJIES: Pedagogik Journal of Islamic Elementary School 
dalam kemampuan kognitif, afektif, dan psikomotorik. Untuk memperoleh hasil belajar maka dilakukan evaluasi untuk mengukur tingkat penguasaan peserta didik terhadap materi. Penilaian hasil belajar merupakan suatu cara untuk mengetahui tercapai atau tidaknya tujuan pembelajaran yang telah ditetapkan. Hasil belajar matematika merupakan perubahan yang terjadi pada peserta didik setelah mempelajari materi matematika. Satriani (2015:13-14.). Seseorang dikatakan belajar apabila terjadi perubahan dalam dirinya dari tidak tahu menjadi tahu. Aunurrahman (2014:38).

Mengingat peran matematika sangatlah penting maka pemahaman peserta didik harus diperhatikan oleh pendidik. Karena pendidik secara langsung terlibat dalam proses pembelajaran. Oleh karena itu, guru mempunyai peranan penting dalam menentukan hasil belajar peserta didik yang dicapai. Hasri (2013:8). Hasil belajar peserta didik diperoleh setelah peserta didik melalui proses pembelajaran. Karena belajar merupakan usaha seseorang untuk memperoleh perubahan. Ahmad Susanto (2014:5). Perubahan yang terjadi haruslah mengalami peningkatan.

Penjelasan di atas mengenai penggunaan media konkret dapat meningkatkan hasil belajar peserta didik pokok bahasan garis bilangan, olehnya itu peneliti merancang sebuah penelitian yang berjudul "Penggunaan Media Konkret untuk Meningkatkan Hasil Belajar Matematika Pokok Bahasan Garis Bilangan pada Peserta Didik Kelas III MI Datok Sulaiman Kota Palopo".

\section{METODE}

Jenis penelitian yang digunakan dalam penelitian ini adalah Penelitian Tindakan Kelas (PTK). Penelitian Tindakan Kelas (PTK) berasal dari bahasa Inggris, yakni classroom action research yang berarti penelitian dengan tindakan yang dilakukan di kelas. Penelitian tindakan merupakan penelitian yang bersifat praktis tanpa membutuhkan waktu khusus. Sedangkan McNiff memandang PTK sebagai penelitian yang dilakukan oleh guru dan hasilnya dapat dimanfaatkan untuk mengembangkan keahlian mengajar dan pengembangan sekolah. Pelaksanaan tindakan yang dilakukan dalam penelitian ini mengikuti Model Hopkins yang menjelaskan bahwa ada 4 hal yang harus dilakukan dalam proses penelitian yakni perencanaan, tindakan, observasi, refleksi. Wina Sanjaya (2015:53-54). Penelitian ini dilaksanakan di kelas III MI Datok Sulaiman Kota Palopo pada semester ganjil tahun pelajaran 2018/2019. Subjek dalam penelitian ini adalah seluruh peserta didik kelas III MI Datok Sulaiman Kota Palopo yang berjumlah 28 orang yang terdiri dari 14 orang laki-laki dan 14 orang perempuan. Sumber data yang digunakan dalam mendukung penelitian ini diantaranya a) Sumber data primer diperoleh dari 


\section{6 | Sri Sulviani}

hasil tes belajar peserta didik melalui penggunaan media konkret dan hasil observasi aktivitas peserta didik serta hasil observasi aktivitas guru dan wawancara. b) Sumber data sekunder diperoleh dari sumber data tertulis berupa dokumen sekolah. Teknik yang digunakan untuk mengumpulkan data penelitian ini adalah tes, observasi, dan dokumentasi. Pengolahan data pada penelitian ini dilakukan setelah terkumpulnya data. Selanjutnya dianalisis secara kuantitatif dan kualitatif. Untuk analisis secara kuantitatif digunakan analisis deskriptif yaitu skor rata-rata dan persentase. Sedangkan analisis kualitatif dilakukan terhadap data yang diperoleh melalui observasi aktivitas peserta didik dan guru dalam pembelajaran garis bilangan dengan menggunakan media konkret. Untuk memperoleh data hasil tes belajar peserta didik dianalisis secara kuantitatif dengan menggunakan rumus ratarata nilai peserta didik $X=\frac{\sum X}{N}$. Suharsimi Arikunto (2009:264). Kemudian nilai kemampuan peserta didik dipersentasekan ke dalam rumus persentase sederhana $\mathrm{P}=\frac{F}{N} \times 100 \%$. Anas Sudijono (2009:43). Hasil penelitian yang telah didapatkan tersebut kemudian diklasifikasikan kedalam bentuk penskoran nilai peserta didik dengan menggunakan kategori persentase skor penilaian. Muhibbin Syah (2009:151) Jika nilai peserta didik mencapai <70 termasuk kategori tuntas dan nilai peserta didik $>70$ termasuk kategori tidak tuntas.

\section{HASIL DAN PEMBAHASAN HASIL PENELITIAN}

1) Gambaran hasil belajar peserta didik dan aktivitas peserta didik serta aktivitas guru melalui penerapan media konkret

Penggunaan media konkret dalam pembelajaran penjumlahan dan pengurangan bilangan bulat positif melalui garis bilangan pada peserta didik kelas III MI Datok Sulaiman Kota Palopo yaitu guru menjelaskan penggunaan media konkret untuk menyelesaikan soal latihan yakni $2+3=\ldots$. Guru meletakkan boneka di atas angka 0 kemudian digeser kearah angka 2 lalu digeser ke angka 3 maka bonekanya berakhir diangka 5. Media konkret yang digunakan dapat dilihat pada gambar berikut: 


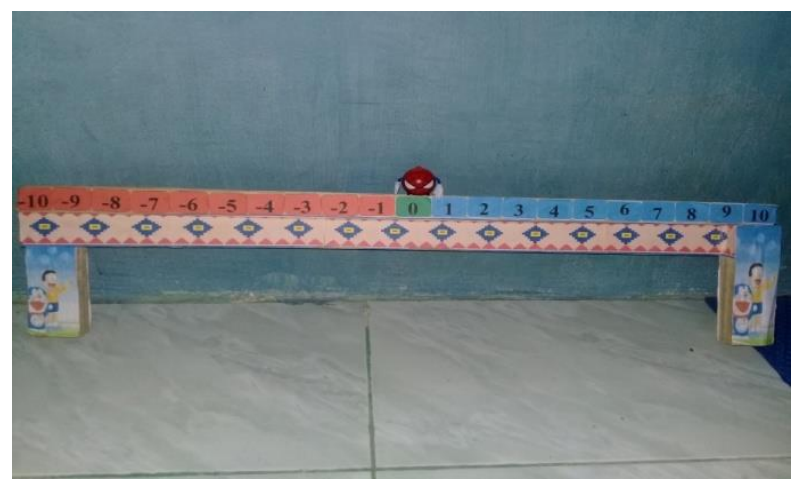

Dalam proses pembelajaran terdapat masih banyak peserta didik yang belum memahami materi operasi hitung penjumlahan dan pengurangan bilangan bulat melalui garis bilangan sehingga kesulitan mengerjakan soal yang diberikan oleh guru. Untuk memudahkan peserta didik, guru memberikan contoh penggunaan media konkret dengan membuat permainan agar peserta didik lebih antusias. Selanjutnya Guru membimbing peserta didik dalam mengerjakan operasi hitung penjumlahan dan pengurangan bilangan bulat.

Hasil evaluasi peserta didik pada siklus I menunjukkan ada 1 peserta didik (4\%) dikategorikan sangat baik, 10 peserta didik (36\%) dikategorikan baik, 12 peserta didik (43\%) dikategorikan cukup, 5 peserta didik (18\%) dikategorikan kurang dan tidak ada peserta didik yang mendapat nilai kategori gagal. Oleh karena itu, secara umum hasil belajar peserta didik bisa dikatakan rendah, karena baru ada 11 peserta didik (39\%) yang nilainya dapat memenuhi Kriteria Ketuntasan Minimal (KKM).

Hasil evaluasi peserta didik pada siklus II menunjukkan ada 23 peserta didik (82\%) dikategorikan sangat baik, 3 peserta didik (11\%) dikategorikan baik, 2 peserta didik (7\%) dikategorikan cukup, dan tidak ada peserta didik yang mendapat nilai kategori kurang dan gagal. Oleh karena itu, secara umum hasil belajar peserta didik bisa dikatakan sangat baik, karena ada 26 peserta didik (93\%) yang nilainya dapat memenuhi Kriteria Ketuntasan Minimal (KKM).

Tahap observasi pada siklus I tercatat sikap yang terjadi pada setiap peserta didik dan guru terhadap pelajaran matematika pokok bahasan garis bilangan melalui penggunaan media konkret. Hasil observasi aktivitas peserta didik pada siklus I mencapai 56\% dan pada siklus II mencapai 85\%. Sedangkan hasil observasi guru pada siklus I mencapai $30 \%$ dan pada siklus II mencapai 30\%.

2) Peningkatan hasil belajar matematika peserta didik pokok bahasan garis bilangan melalui penggunaan media konkret 


\section{8 | Sri Sulviani}

Penggunaan media konkret pada pembelajaran operasi hitung penjumlahan dan pengurangan bilangan bulat melalui garis bilangan, hasil belajar peserta didik mengalami peningkatan dapat dilihat dari hasil tes belajar peserta didik dan aktivitas peserta didik semakin meningkat dapat dilihat dari lembar observasi yang telah dilakukan. Berdasarkan uraian tersebut, secara keseluruhan semua kriteria aktivitas guru dan peserta didik dan analisis tes hasil belajar peserta didik telah memenuhi kriteria yang ditetapkan pada indikator keberhasilan dari siklus I ke siklus II mengalami peningkatan. Sehingga dapat dikatakan bahwa peningkatan hasil belajar matematika pokok bahasan garis bilangan dapat terjadi karena penggunaan media konkret.

Adapun nilai tes evaluasi pada MI Datok Sulaiman Kota Palopo yang dilakukan peneliti setiap siklus yang menandakan hasil belajar peserta didik pokok bahasan garis bilangan meningkat yaitu prasiklus ke siklus I sebesar 35\% dan siklus I ke siklus II sebesar 54\%.

Berikut perbandingan hasil pembelajaran tahap pra siklus, siklus I dan siklus II dapat dilihat pada diagram berikut ini:

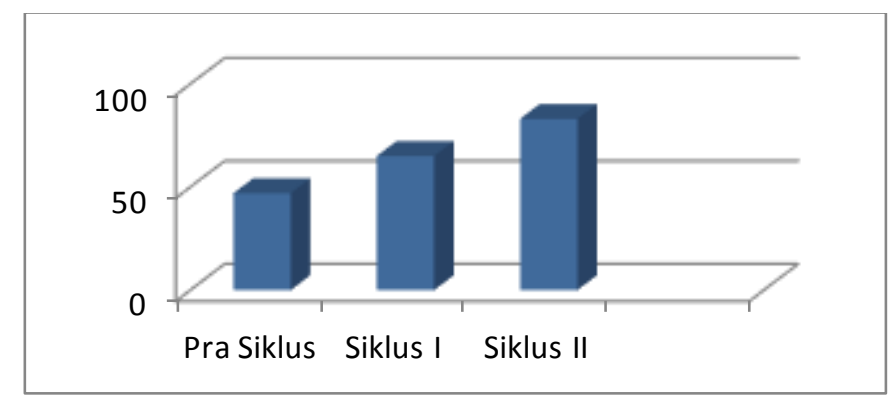

Maka, dengan menggunakan media konkret pokok bahasan garis bilangan dapat meningkatkan hasil belajar peserta didik kelas III MI Datok Sulaiman Kota Palopo.

\section{PEMBAHASAN}

Proses pembelajaran terdapat masih banyak peserta didik yang belum memahami materi operasi hitung penjumlahan dan pengurangan bilangan bulat positif melalui garis bilangan sehingga kesulitan mengerjakan soal yang diberikan oleh guru. Untuk memudahkan peserta didik dalam mengerjakan soal, guru memberikan contoh penggunaan media konkret dengan membuat permainan agar peserta didik lebih tertarik dan antusias. Selanjutnya Guru membimbing peserta didik dalam mengerjakan soal dengan bantuan media konkret.

PiJIES: Pedagogik Journal of Islamic Elementary School 
Hasil penelitian yang dilakukan sebanyak 2 siklus menunjukkan bahwa media konkret mampu meningkatkan hasil belajar peserta didik. hal ini disebabkan karena media pembelajaran yang digunakan sesuai dengan materi yang diajarkan. Menurut Gagne' dan Briggs, "media pembelajaran merupakan alat untuk menyampaikan materi pembelajaran." Azhar Arsyad (2016:4). Hasil belajar peserta didik digunakan untuk mengetahui sejauh mana pemahaman peserta didik terhadap materi pembelajaran yang dinyatakan dalam bentuk nilai. Menurut Nawawi "hasil belajar diartikan sebagai tingkat keberhasilan peserta didik di sekolah yang dinyatakan dalam bentuk nilai yang diperoleh dari hasil tes mengenal sejumlah materi pelajaran tertentu." Ahmad Susanto (2014:5). Menurut Winkel "hasil belajar merupakan perubahan yang mengakibatkan manusia berubah dalam sikap dan tingkah lakunya." Purwanto (2014:45). Dengan demikian peserta didik yang telah melalui proses evaluasi berarti guru berupaya memperbaiki kekurangan dari hasil yang diperoleh peserta didik sebelumnya.

Berdasarkan persentase ketuntasan hasil belajar peserta didik kelas III MI Datok Sulaiman Kota Palopo setelah menggunakan media pembelajaran yaitu media konkret pada pembelajaran matematika, dapat dilihat bahwa banyaknya peserta didik yang tidak tuntas pada siklus I sebanyak 11 peserta didik atau 39\% dan banyaknya peserta didik yang tidak tuntas sebanyak 17 peserta didik atau 60\%, sedangkan peserta didik yang tuntas pada siklus II sebanyak 26 peserta didik sekitar $93 \%$ dan banyaknya peserta didik yang tidak tuntas sebanyak 2 peserta didik atau $7 \%$. Aktivitas peserta didik dengan penerapan media konkret juga mengalami peningkatan dari siklus I sebesar 56\% dan siklus II $85 \%$ serta aktivitas guru dari siklus I diperoleh $30 \%$ dan siklus II $37 \%$.

Indikator keberhasilan dalam penelitian ini telah tercapai, dalam hal ini ketuntasan peserta didik secara klasikal telah mencapai 80\% dengan ketuntasan $93 \%$ dan rata-rata hasil belajar peserta didik telah mencapai nilai $>70$ serta aktivitas peserta didik dan guru mengalami peningkatan. Ini berarti hasil belajar matematika pokok bahasan garis bilangan peserta didik kelas III MI Datok Sulaiman Kota Palopo dengan menggunakan media konkret dapat meningkat. 


\section{0 | Sri Sulviani}

\section{PENUTUP}

Hasil analisis data penelitian, serta rumusan masalah maka dapat disimpulan bahwa: 1) Gambaran hasil belajar peserta didik kelas III MI Datok Sulaiman Kota Palopo dengan penerapan media konkret yaitu rata-rata hasil belajar peserta didik diperoleh prasiklus dikategorikan gagal dengan nilai rata-rata 47 atau secara klasikal sebesar 4\%, pada siklus I dikategorikan cukup dengan nilai rata-rata 64,85 atau secara klasikal sebesar 39\%, dan pada siklus II dikategorikan sangat baik dengan nilai rata-rata 82,89 atau secara klasikal sebesar 93\%. Dengan demikian, pembelajaran telah mencapai ketuntasan belajar sesuai dengan indikator yang telah ditetapkan. Aktivitas peserta didik juga mengalami peningkatan dengan penerapan media konkret yakni pada siklus I diperoleh 56\% dan siklus II 85\% serta aktivitas guru diperoleh siklus I 30\% dan siklus II 37\%. 2) Melalui penggunaan media konkret hasil belajar matematika pokok bahasan garis bilangan pada peserta didik kelas III MI Datok Sulaiman Kota Palopo mengalami peningkatan. Peningkatan dari prasiklus ke siklus I sebesar 35\% dan siklus I ke siklus II sebesar $54 \%$.

\section{DAFTAR PUSTAKA}

Arikunto, Suharsimi $d k k$. 2014. Penelitian Tindakan Kelas. Cet. XII; Jakarta: Bumi Aksara. . 2009. Dasar-Dasar Evaluasi Pendidikan. Ed. Revisi. III; Jakarta: Bumi Aksara.

Arsyad, Azhar. 2016. Media Pembelajaran. Cet. XIX; Jakarta: RajaGrafindo Persada.

Asnawir dan Basyiruddin Usman. 20012. Media Pembelajaran. Cet. I; Jakarta: Ciputat Pers.

Aunurrahman. 2014. Belajar dan Pembelajaran. Cet. IX; Bandung: Alfabeta.

Djamarah, Syaiful Bahri dan Aswan Zain. 2012. Strategi Belajar Mengajar. Cet. II; Jakarta: Asdi Mahasatya.

Hamzah, Ali dan Muhlisrarini. 2014. Perencanaan dan Strategi Pembelajaran Matematika. Cet. I; Jakarta: RajaGrafindo Persada

Hasri. 2013. Meningkatkan Hasil Belajar Matematika Melalui Penggunaan Alat Peraga pada Siswa Kelas VII MTs Negeri Model Palopo, Jurnal Kependidikan dan Penelitian Konsepsi. Palopo: Pusat Pengembangan Pendidikan Indonesia Luwu Raya Vol. 2 No. 1.

Ibrahim, R. dan Syaodih. 2010. Perencanaan Pengajaran. Jakarta: Rinika Cipta.

Jihad, Asep dan Abdul Haris. 2013. Evaluasi Pembelajaran. Yogyakarta: Multi Pressindo.

PiJIES: Pedagogik Journal of Islamic Elementary School 
Kementrian Agama Republik Indonesia. 2016. Al-Quran Al-Karim Samara Tajwid dan Terjemah Edisi Wanita, Surabaya: Halim.

Kunandar. 2011. Langkah Mudah Penelitian Tindakan Kelas Sebagai Pengembangan Profesi Guru. Cet. VII; Jakarta: Rajawali Pers.

Maharani, Ervina. 2014. Panduan Sukses Menulis Penelitian Tindakan Kelas Yang Simpel, Cepat, Dan Memikat. Cet. I; Yogyakarta: Parasmu.

Masitoch, Nurul dkk. 2009. Gemar Matematika untuk SD dan MI Kelas III. Jakarta: Pelita Ilmu.

Purwanto. 2014. Evaluasi Hasil Belajar. Yogyakarta: Pustaka Belajar.

Runtukahu, Tombokan dan Selpius Kandou.2014. Pembelajaran Matematika

Dasar bagi anak berkesulitan belajar. Cet.I; Yogyakarta: Ar-Ruzz Media.

Rusman. 2016. Model-Model Pembelajaran Mengembangkan Profesionalisme Guru. Cet. VI; Jakarta: Rajawali Pers.

Rustan, E. (2001). Budaya Leluhur dalam Memperkukuh Tatanan Masyarakat di Era Globalisasi. In Seminar Internasional Pemertahanan Identitas Masyarakat Multikultural di Era Globalisasi (pp. 79-86). Surabaya.

Rustan, E., Hanifah, N., \& Kanro, B. (2018). De-radicalization in the Implementation of Islamic Education Curriculum in SMA Masamba South Sulawesi. Dinamika Ilmu, 18(2), 271-283. https://doi.org//10.21093/di.v18i2.1338

S. Sadiman, Arief. 2012. Media Pendidikan Pengertian, Pengembangan, dan Pemanfaatannya. Cet. XVI; Depok: Rajawali Pers.

Sanjaya, Wina. 2015. Penelitian Tindakan Kelas. Jakarta: Prenadamedia Group.

Satriani. 2015. Meningkatkan Hasil Belajar Siswa dalam Materi Operasi Hitung Bilangan Bulat melalui Pendekatan CTL (Contextual Teaching Learning) pada Kelas IV MIS Datok Sulaiman Palopo, Skripsi. Program Studi Pendidikan Matematika Fakultas Tarbiyah dan Ilmu Keguruan Institut Agama Islam Negeri (IAIN) Palopo.

Sudijono, Anas. 2016. Pengantar Evaluasi Pendidikan. Cet.VI; Jakarta: Raja GrafindoPersada.

2009. Pengantar Statistik Pendidikan, Ed. Ke-I; Jakarta: Raja Grafindo Petrsada.

Suharyono. 2009. Matematika untuk SD/MI Kelas III. Jakarta: Pusat Perbukuan.

Susanto, Ahmad. 2014. Teori Belajar \& Pembelajaran di Sekolah Dasar. Cet. I; Jakarta: Kencana.

Syah, Muhibin. 2009. Psikologi Pendidikan, Ed. Revisi. IX; Jakarta: RajawaliPers. 


\section{2 | Sri Sulviani}

Tim Penyusun Kamus Pusat Bahasa- ed. 3, 2011. Kamus Besar Bahasa Indonesia. Cet. IV; Jakarta: Balai Pustaka. 